\title{
EXIT CONSENTS IN SOVEREIGN BOND EXCHANGES
}

\author{
Lee C. Buchheit ${ }^{*}$ \\ G. Mitu Gulati**
}

The external debt of emerging market sovereign borrowers is now mainly in the form of bonds held by numerous institutional and individual bondholders. Many of these bonds are governed by the law of the state of New York. As a matter of drafting convention, bonds for sovereign issuers governed by New York law prohibit amendments to the payment terms of the instruments (the amount and the due dates of payments) without the consent of each affected bondholder. If a sovereign issuer finds it necessary to seek a restructuring of its bond indebtedness, it must therefore implement the restructuring by offering to exchange its old bonds for new debt instruments that reflect the new financial terms; a technique that inevitably risks leaving behind "holdout" creditors who may refuse to accept the proposed restructuring. Holdouts pose a litigation threat to the sovereign and may even jeopardize the sovereign's ability to service the new bonds it has issued to the other creditors participating in the exchange.

A number of ideas-ranging from international bankruptcy codes and stays of creditor legal remedies administered by the International Monetary Fund (IMF), to reforming the explicit terms of sovereign bond contracts- have been suggested as a means of dealing with the holdout creditor threat. This Article suggests a less radical, and more immediately applicable, alternative: allowing the majority creditors to use the amendment clauses in their existing bonds to change certain nonpayment terms contained in those bonds (such as financial covenants or waivers of sovereign immunity) as a means of encouraging prospective holdouts to participate in the exchange. Because the sovereign issuer solicits the consent of its creditors to amend the old bonds just as those lenders exchange their bonds for the sovereign's new debt instruments, this technique is referred to as an "exit" consent.

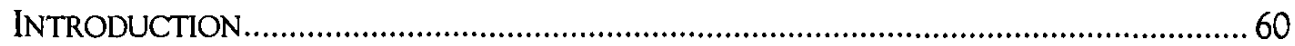

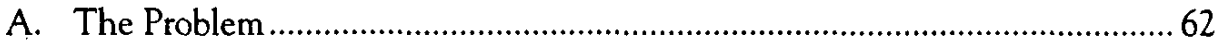

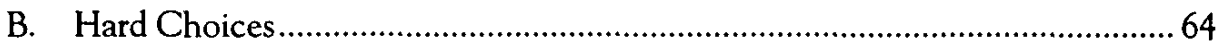

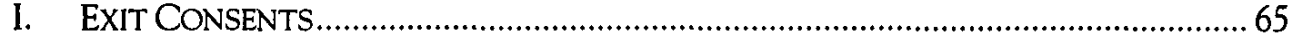

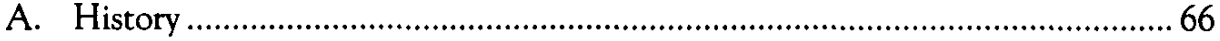

* Partner: Cleary, Gottlieb, Steen \& Hamilton (New York).

** Acting Professor of Law, University of California at Los Angeles. We are grateful to William Bratton, Zohar Goshen, Andrew Guzman, Marcel Kahan, Ken Klee, William Klein, Frederick Lambert, Lynn LoPucki, Kal Raustiala, Steven Schwarcz, and Andrew Yianni for their comments. Responsibility for errors and for the views expressed lies solely with the authors. 


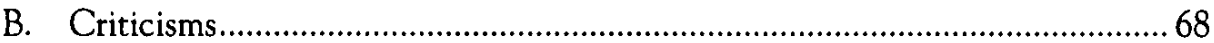

C. Legal Validity of Exit Consents ..................................................................... 70

1. The Position of the Bond Issuer............................................................... 70

2. The Sovereign Context ....................................................................... 74

3. The Position of the Exiting Bondholders ................................................. 75

D. Exit Amendments in Sovereign Bonds .......................................................... 78

E. The Justification for Using Exit Amendments in Sovereign

Bond Exchanges

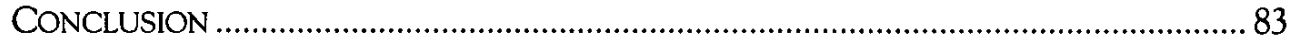

\section{INTRODUCTION}

The official sector proponents of the new financial architecture, mainly the G-10 governments and international financial institutions like the International Monetary Fund (IMF), have made it clear that private holders of sovereign bonds should not expect to be bailed out by official sector monies in future sovereign debt workouts. ${ }^{1}$ In practical terms, this means that private bondholders will be asked to reduce or to reschedule their claims against a financially distressed sovereign that has sought official sector assistance in the form of multilateral credit facilities or a rescheduling of debts owed to other governments.

The large majority of bondholders can be expected to participate in such reschedulings: They have few good alternatives. ${ }^{2}$ But what is to stop a few bondholders from refusing to participate and instead demanding preferential payouts? $?^{3}$ This question has consumed much of the intellectual energy in the

1. See Group of Ten, The Resolution of SOVEREIGN Liduidity CRISES 18-20 (1996); G-22, REPORT OF THE WORKING GROUP ON INTERNATIONAL FINANCIAL CRISES 27-28 (1998); IMF, INVOLVING THE PRIVATE SECTOR IN FORESTALLING AND RESOLVING FINANCIAL CRISES 43 (1999).

2. The value of a sovereign's assets held outside of its own territory typically represents only a small fraction of the total claims against the country by foreign creditors. Any wholesale attempt at litigation and seizure of assets following a sovereign default will therefore leave most creditors unsatisfied. Debtholders have generally opted to negotiate, rather than to litigate, their way out of sovereign debt problems.

3. During the global debt crisis of the 1980 s, the debts were held primarily by commercial banks. The banking community as a whole was remarkably successful in controlling its maverick element. See Barry Eichengreen, Bailing in the Private Sector: Burden Sharing in International Financial Crisis Management, 23 FLETCHER F. WORLD AFF. 57, 62 (1999). In the few instances in which this intercreditor pressure proved inadequate to forestall litigation, the sovereign borrowers raised a variety of legal defenses including, in U.S. courts, the doctrines of act of state, comity, and champerty. These defenses sometimes slowed, but rarely averted, a judgment in favor of the plaintiff. See Lee C. Buchheit, The Debt Rescheduling Process: Pitfalls and Hazards, in 5 CURRENT LEGAL ISSUES AFFECTING CENTRAL BANKS 353, 357-58 (Robert C. Effros ed., 1998). For two recent Second Circuit decisions on the subject, see Elliott Associates, L.P., v. Banco de la Nacion, 194 F.3d 363, 371-81 (2d Cir. 1999) (rejecting a champerty defense), and Pravin Banker Associates, 
new financial architecture debate. ${ }^{4}$ Some commentators have proposed an international bankruptcy code applicable to sovereign debt workouts that would prevent maverick creditors from delaying, derailing, or exploiting a debt restructuring acceptable to most lenders. ${ }^{5}$ Others favor stays on creditor legal actions administered by the IMF as a means of disarming mavericks. ${ }^{6}$ The less dramatic have argued for changes in sovereign bond documentation governed by the law of a U.S. jurisdiction that would permit the majority of creditors to make decisions affecting the payment terms of the instrument - changes that would bind all holders, regardless of whether they joined in approving the amendment. ${ }^{7}$

Ltd. v. Banco Popular del Peru, 109 F.3d 850, 855 (2d Cir. 1997) (rejecting a comity defense). See also Samuel E. Goldman, Comment, Mavericks in the Market: The Emerging Problem of Hold-Outs in Sovereign Debt Restructuring, 5 UCLA J. INT'L L. \& FOREIGN AFF. (forthcoming 2000) (discussing the cases and the use of the various defenses).

4. This Article focuses on the problem of recalcitrant creditors after a debt crisis has begun. The new financial architecture debate has also considered ways to prevent these crises from occurring in the first place. See Eichengreen, supra note 3, at 60 (dividing proposed changes to the international financial architecture into the categories of ex ante and ex post measures).

5. See Kenneth Rogoff, International Institutions for Reducing Global Financial Instability, J. ECON. PERSP., Fall 1999, at 21, 30 (discussing, in the context of describing and evaluating other proposals, the proposals for an international bankruptcy court); Jeffrey D. Sachs, Do We Need an International Lender of Last Resort, Frank D. Graham Lecture, Princeton University (Apr. 20, 1995) (on file with author) (proposing the establishment of an international bankruptcy tribunal); $c f$. Steven L. Schwarcz, Sovereign Debt Restructuring: A Bankruptcy Reorganization Approach, 85 CORNELL L. REV. 956 (2000) (proposing, as an alternative to an international bankruptcy court, an international convention for sovereign debt restructuring that would be based on U.S. bankruptcy reorganization principles).

6. See Michel Camdessus, Capital Flows, Crises and the Private Sector, Remarks before the Institute of International Bankers (Mar. 1, 1995) (proposing a change to the International Monetary Fund's (IMF's) Articles of Agreement that would permit a temporary stay on creditor remedies); $c f$. Stephen Bainbridge, Comity and Sovereign Debt Litigation: A Bankruptcy Analogy, 10 MD. J. INT'L L. \& TRADE 1, 4 (1986) (arguing for recognition of debt moratoria based on principles of comity); Marcus Miller \& Lei Zhang, Sovereign Liquidity Crises: The Strategic Case for a Payments Standstill, available at http://www.warwick.ac.uk/fac/soc/CSGR/wpapers/wp3599.PDF (last visited July 2, 2000) (arguing, by analogy to the U.S. bankruptcy context, for a mechanism that would provide a stay of claims against the debtor state).

7. See, e.g., BARRY EICHENGREEN, TOWARD A NEW INTERNATIONAL FINANCIAL ARCHITECTURE 65-67 (1999) (endorsing changes to international lending contracts to allow a majority of debtholders to renegotiate terms in times of trouble); BARRY EICHENGREEN \& ASHOKA MODY, WOULD COLlECTIVE ACTION ClAUSES RAISE BORROWING COSTS? (Nat'l Bureau of Econ. Research, Working Paper No. 7458, 2000) (recommending, in the context of a study of the costs of including collective action clauses in bond contracts, that such clauses be included); BARRY EICHENGREEN \& RICHARD PORTES, CRISIS? WHAT CRISIS? ORDERLY WORKOUTS FOR SOVEREIGN DEBTORS 56 (1995) (endorsing changes to international lending contracts to allow a majority of debtholders to renegotiate terms in times of trouble); Stanley Fischer, On the Need for an International Lender of Last Resort, J. ECON. PERSP., Fall 1999, at 85, 99 (noting, in the context of discussing the various proposals to reform the global financial architecture, the $G-10$ proposal that bond contracts be modified to permit creditors to make decisions by majority rather than unanimity). 
Many of these ideas are regarded by the capital markets as quixotic, the rest as either alarming or truly alarming. All of these proposals are hampered, to a greater or lesser extent, by the need to change existing laws, pass new laws, or alter long-standing documentation practices in order to neutralize the perceived threat posed by holdout creditors. But if such changes erode the confidence of the well-intentioned investors in the efficacy of their legal remedies, the private market may simply withdraw from unsecured lending to emerging market sovereigns. ${ }^{8}$ No sovereign borrower wants to hear that it need not worry about the machinations of maverick creditors because it no longer has any creditors. The result is that none of these proposals has come close to being put into practice. Unfortunately, the need for effective sovereign bond workout mechanisms-as the recent experiences of Mexico, South Korea, Russia, Pakistan, Ukraine, and Ecuador illustrate-is immediate. ' It is possible that given time and additional empirical research, one or more of the above-mentioned proposals will be put into play, ${ }^{10}$ but not anytime soon.

This Article discusses a less radical, and more immediately applicable, alternative: using the existing amendment clauses in sovereign bonds to encourage the participation of all bondholders in a sovereign debt restructuring once a supermajority of the bondholders has decided to go along with the deal.

\section{A. The Problem}

The following example will illustrate the problem.

The Republic of Ruritania, a small country not so far away, embraced the title "emerging market" in the early 1990s. If the truth be told, Ruritania gloried in it. To be an emerging market in the 1990s was to receive the benefi-

8. See, e.g., Eichengreen, supra note 3, at 71 (making the point that if contracts and institutional arrangements are altered to make the suspension of debt service too easy, the capital markets will not function at all).

9. See Liz Dixon \& David Wall, Collective Action Problems and Collective Action Clauses, FIN. STABILITY REV., June 2000, at 142, 142.

10. For example, the proposals for the inclusion of collective action clauses in bonds governed by New York law has received vocal support from certain G-10 governments. Empirical research has recently been published suggesting that the inclusion of such clauses is not likely to increase significantly the costs of borrowing. See id. at 150 (describing the efforts of countries such as the United Kingdom and Canada to persuade others to include collective action clauses); Kostas Tsatsaronis, The Effect of Collective Action Clauses on Sovereign Bond Spreads, BANK FOR INT'L SETTLEMENTS Q. REV., Nov. 1999, at 22 (examining the difference in spreads between bonds issued under English law and those issued under U.S. law and not finding statistically significant differences); Barry Eichengreen \& Ashoka Mody, Would Collective Action Clauses Raise Borrowing Costs? An Update and Additional Results 4 (May 2000) (unpublished manuscript, available at http://elsa.berkeley.edu/users/eichengr/governinglawnew.pdf) (updating earlier empirical work on the costs of including collective action clauses in bonds and finding that, at least for borrowers with good credit ratings, the presence of collective action clauses may lower borrowing costs). 
cent attention of that charmingly amnesic creature, the emerging market investor.

Ruritania launched three bond issues governed by New York law during this period: two Eurobonds and one Yankee bond registered in the United States. Fiscal agency agreements were used for each issue, and the bonds were widely distributed.

By late 1999, Ruritania was no longer the market's darling. Depressed prices for the country's primary commodities exports, a dollop of domestic banking crisis, a dash of political instability, and frosting from the August 1998 devaluation crisis in Russia all contributed to drive down the secondary market price of Ruritania's bonds to about $30 \notin$ on the dollar.

The bonds start maturing in 2000 . The private capital markets will not lend Ruritania the money needed to refinance the bonds, multilateral lenders have expressly forbidden Ruritania to use the proceeds from their loans to "bail out" the private bondholders, and Ruritania's international monetary reserves are not sufficient to repay the bonds. In short, Ruritania has no choice but to seek a consensual restructuring of the bonds.

The terms and conditions of each issue of Ruritanian bonds provide that amendments, waivers, and modifications to the bonds may be made with the consent of the issuer and the holders of not less than $662 / 3$ percent in aggregate principal amount of the bonds except that

no such action may, without the consent of the holder of each bond affected thereby, (1) change any due date for the payment of the principal of or interest on the bonds or (2) reduce the principal amount of the bonds or the interest rate thereon.

In the opinion of Ruritania's financial advisers, it is fanciful to believe that all bondholders will accept a deferment of payments, much less a reduction in the principal amount of their claims or the rate of interest payable on the bonds. A simple amendment of the bonds to achieve these goals is therefore out of the question. Consequently, Ruritania must implement any restructuring of the bonds through an exchange offer in which holders are invited to tender their existing bonds in exchange for new debt instruments that reflect the financial terms of the restructuring."

The financial advisers also believe that not all bondholders can be expected to accept such an exchange offer. Following any exchange, therefore, a group of creditors will continue to hold the old bonds. In some cases, this will result from simple inadvertence: The holders may not hear about the exchange offer in time to respond to it, or their holdings may be thought

11. For a description of the history of this technique in sovereign debt restructurings, see Lee C. Buchheit, Exchanging Places, INT'L FIN. L. REV., May 1991, at 13. 
too small to warrant the effort it would take to send in a response. Other bondholders, however, may deliberately refrain from tendering their bonds in the exchange offer in the belief that they can extract a better settlement from Ruritania once the offer closes. Whatever their motivation, we shall call these bondholders the holdouts. ${ }^{12}$

B. Hard Choices

Ruritania has only three options following completion of the exchange: continue to pay the full amount due on the old bonds retained by the holdouts, pay a portion of the amount due on the old bonds, or default entirely on the old bonds. None of the options is attractive.

Even a rumor that Ruritania intends to continue paying holdouts in full after the exchange will obviously scupper the chances for a successful exchange. ${ }^{13}$ The Ruritanian authorities may also face domestic political criticism for paying creditors that decline to help the country in its hour of need. Finally, paying the holdouts in full and on time makes the bondholders who accepted the offer look pretty silly.

Paying the holdouts a portion of what they are owed, probably in amounts corresponding to what they would have received had they participated in the exchange, is not enough to cure the default on the old bonds or to avoid acceleration and litigation if the old bondholders are so inclined.

12. See Marcel Kahan, Individual and Collective Rights of Bondholders 19 (June 2000) (unpublished manuscript, on file with authors) (describing the holdout problem in the bond context).

13. For example, in two recent sovereign bond exchange offers undertaken for the purpose of effecting a rescheduling of external indebtedness (those by Pakistan in December 1999 and by the Ukraine in February 2000), the sovereign issuers went out of their way to send a strong warning to holders of existing debts who may have been toying with the idea of declining the exchange. Pakistan said:

The [Islamic] Republic [of Pakistan] does not propose to make any offers to holders of the Existing Notes other than this Exchange Offer. Accordingly, the Republic does not propose to settle amounts due under the Existing Notes with holders who do not participate in this Exchange Offer on terms which are more favourable than those contained in this Exchange Offer.

The Islamic Republic of Pak., Offer to Exchange U.S. Dollar 10 Per Cent. Notes Due 2002/2005, at A-5 (Nov. 15, 1999).

The Ukraine was even more blunt:

In light of the severity of the liquidity crisis confronting it, Ukraine is not in a position to, and will not, make any offer to holders of the Existing Notes other than this Exchange Offer. Ukraine will not entertain any settlement with holders of Existing Notes who elect not to participate in this Exchange Offer on terms which are more favourable than those contained in this Exchange Offer.

THE CABINET OF MINISTERS OF UKR., OFFERS TO EXCHANGE EURO 10 PER CENT. AMORTISING Notes Due 2007 ("Euro New Notes") OR U.S. DOllar 11 Per CENT. AMORTISING Notes DUE 2007 ("DOllar NEW NOTES") 4 (Feb. 9, 2000). 
A policy of partial payment, the sovereign hopes, will placate old bondholders and dissuade them from legal action. It is at best a temporizing measure. The old bondholders will eventually want the unpaid portion of their claim to be settled.

Not paying the holdouts, however, drags its own tin can of problems. Most sovereign bonds require a vote of holders owning more than 25 percent of the bonds in order to accelerate unmatured principal following the occurrence of an event of default. Prior to an exchange, the presence of indulgent bondholders may keep a small group of dissidents from accelerating the instrument. After an exchange, however, the only creditors left in the old bond will be holdouts, and the risk of an acceleration of that instrument, followed by litigation and all of its associated unpleasantries, will be high. In the worst case scenario, the holdouts may attempt to attach the stream of payments due on the new bonds and divert those funds to the accelerated payout of the old bonds. ${ }^{14}$ This would make the exchanging bondholders look stupendously silly.

What Ruritania needs-and what the bondholders who intend to accept the exchange offer should fervently want Ruritania to find-is some means of either discouraging prospective holdouts from holding out or, failing that, neutralizing the threat posed by the holdouts to the normal servicing of the new bonds issued in the exchange.

\section{EXIT CONSENTS}

One solution may lie in the amendment clauses that appear in Ruritania's bonds governed by New York law. As noted above, these clauses preclude any changes to the payment terms of the bonds (namely, the amount and due dates of payments) without the consent of each affected bondholder. ${ }^{15}$ But any other provision of the bond can be amended with the consent of the issuer and, in our example, holders representing only $662 / 3$ percent of the outstanding amount of the bonds. Many sovereign bonds set this threshold as low as 50 percent. As part of the exchange offer, Ruritania could therefore

14. See infra text accompanying notes $81-82$ for a discussion of a possible change to the waiver of a sovereign immunity clause that might prevent holdouts from obtaining prejudgment attachment of payment streams due on the issuer's other obligations.

In September 2000, a judgment creditor of Peru, which had refused to participate in Peru's Brady restructuring, attempted to attach the stream of judgments due on Peru's. Brady bonds. See Joshua Chaffin, Further Fall by Peruvian Bradys, FIN. TIMES, Sept. 21, 2000, at 28.

15. Compare this to the normal practice in bonds governed by the law of England in which changes to payment terms may be made by vote of a supermajority of holders and, if so made, will bind all holders. See Andrew Yianni, Resolution of Sovereign Financial Crises-Evolution of the Private Sector Restructuring Process, FIN. STABILITY REV., June 1999, at 78, 80-81. 
seek the consent (exit consent) of this supermajority of bondholders to amend provisions in the bonds they are tendering in the exchange (exit amendments) in order to render those old bonds less attractive to any bondholder who may be thinking of declining the exchange and staying behind.

Through an exit amendment, therefore, the specified majority or supermajority of bondholders exercises its power to amend the old bond-just before those creditors leave the old bond - as an incentive for all other holders to come along with them. The commercial rationale for this action is that holdout creditors are at least as much of a threat to the interests of the majority bondholders as they are to the sovereign issuer. A sovereign borrower emerging from a debt crisis will have only limited resources to apply toward the servicing of its external debt. The financial terms of the new instrument being offered to creditors in an exchange will therefore reflect the borrower's anticipated future debt-servicing capacity. Any significant group of holdout creditors will, after the exchange, be able to accelerate the old bond and possibly extract a preferential financial settlement from the sovereign debtor that could jeopardize the sovereign's ability to continue servicing the new bonds issued in the exchange.

Once a bondholder decides to accept an exchange offer, it has every commercial reason to want all other bondholders to do likewise. An amendment to the old bond that is accepted by the exiting creditors (assuming they aggregate the necessary majority or supermajority required for amendments to nonpayment terms) can render the old bond a less hospitable abode for prospective holdouts.

\section{A. History}

There is nothing novel about using the amendment clauses in bonds to implement the will of a majority of creditors. Bonds governed by English law typically permit a supermajority of bondholders to change even payment terms and those amendments then bind all holders. ${ }^{16}$ Prior to 1939 , many bonds issued in the United States took the same approach. Following the stock market crash of 1929, however, the equity owners of some American companies began buying up those companies' bonds at heavily discounted prices. Once the equity holders had achieved the necessary majority or supermajority required to push through amendments to the bonds, they sometimes used this power to forgive or defer payments on the bonds, thus allowing

16. See id. A Deutsche Bank study of sovereign Eurobonds revealed that 25 percent are governed by English law, and the remainder governed by New York law. See Peter Petas \& Rashique Rahman, Sovereign Bonds-Legal Aspects that Affect Default and Recovery, GLOBAL EMERGING MARKETS, May 1999, at 59, 60. 
all of the company's resources to be made available to equity holders. This amounted to an effective inversion of the normal priority of claims in bankruptcy under which debtholders are paid out before equity holders. ${ }^{17}$

To correct this abuse, Congress included in the Trust Indenture Act of 1939 an absolute prohibition on any involuntary reduction in the amount of a bondholder's monetary claim, outside of a formal bankruptcy proceeding, and prevented any involuntary deferments of payments beyond three years from the original due dates. ${ }^{18}$ These restrictions applied only to indentures that must be qualified under the Trust Indenture Act (mainly corporate bonds issued to the public), but they established a documentation standard that has, with few exceptions, been followed even for foreign sovereign bonds issued in the United States or under the law of a U.S. jurisdiction. ${ }^{19}$ In our Ruritanian example, Ruritania's bonds governed by New York law, whether issued in the United States as Yankee bonds or outside as Eurobonds, incorporate this conventional prejudice of American bond drafters against involuntary amendments to payment terms.

As a technique to facilitate the restructuring of corporate bonds, exit consents gained some notoriety in the 1980s. This was an era of sizable highyield ("junk") bond offerings by American corporations. ${ }^{20}$ Inevitably, some of these bonds could not be serviced on their original terms and the issuers were faced with the need to restructure the instruments.

Unlike the Republic of Ruritania, of course, a corporate bond issuer always has the option of bankruptcy as a means of achieving a restructuring of its debts. In a reorganization of a U.S. company's affairs under Chapter 11 of the Bankruptcy Code, a plan of reorganization that is acceptable to most members of a class of creditors can be imposed on a dissident minority. ${ }^{21}$ Bankruptcy, however, is rarely a pleasant alternative. Among other things,

17. For a description of this history, see Mark J. Roe, The Voting Prohibition in Bond Workouts, 97 YALE L.J. 232, 250-58 (1987).

18. See 15 U.S.C. $\$ 77$ ppp(a)-(b)(1994).

19. See Lee C. Buchheit, Majority Action Clauses May Help Resolve Debt Crises, INT'L FIN. L. REV., Aug. 1998, at 13, 14; see also Eichengreen, supra note 3, at 64.

20. See, e.g., Bryant B. Edwards \& Jon J. Bancone, Modifying Debt Securities: The Search for the Elusive "New Security" Doctrine, 47 BUS. LAW. 571, 571-72 (1992).

21. Dissident bondholders within a class can be forced to consent as long as there is approval from two-thirds of the class in amount and a majority of the claims in number. See 11 U.S.C. $\$ \S 1126(\mathrm{c}), 1129(\mathrm{a})(8)(1994)$. In some circumstances, the plan can also bind a dissenting class of creditors (this is referred to as a "cram down"). See 11 U.S.C. $\$ 1129$ (b) (1994); Kenneth N. Klee, All You Ever Wanted to Know About Cram Down Under the New Bankruptcy Code, 53 AM. BANKR. L.J. 133, 134 (1979). See generally Kenneth N. Klee, Cram Doun II, 64 AM. BANKR. L.J. 229 (1990). 
incumbent managers of a bankrupt company often lose their jobs in the process of reorganization. ${ }^{22}$

A few corporate bond issuers in the 1980 s therefore sought to replicate the attractive feature of a formal bankruptcy (the ability to force changes on a dissident minority), without actually putting the company into Chapter 11. Their solution was to use the provision in a bond that permits amendments to nonpayment terms of the instrument with the approval of, typically, holders of one-half or two-thirds of the issue in order to remove features of the bonds such as financial covenants that prospective holdouts might find valuable. ${ }^{23}$ When this was done in the context of an offer by the issuer to exchange those old bonds for new debt instruments, the disfiguring amendments to the old bonds tended to encourage acceptance of the new bonds and thus reduce or eliminate the likelihood of holdouts. ${ }^{24}$

\section{B. Criticisms}

Exit amendments of this kind involve an obvious element of coercion. They are intended, after all, to encourage the prospective holdout creditor to accept an offer that the holdout may not, except for the prospect of being left with a bond stripped of important protective covenants, have otherwise found attractive. Some observers recognized that embedded in these exit consent offers was the potential for coercive mischief that went beyond the therapeutic squeezing of a few benighted holdouts.

Prospective holdouts can be painted as either unenlightened (unable to see the benefits of a deal that is perfectly apparent to the supermajority of their fellow bondholders) or opportunistic (waiting to demand full and timely payment of their bonds once the other creditors give the issuer the debt relief that will make such preferential payments possible). These characterizations assume that the supermajority of bondholders has in fact been persuaded that the financial terms of the new instrument being offered in the exchange are necessary and ultimately in the best interests of all creditors. But what if they are not? Under certain conditions, critics argued, a corporate bond issuer

22. On the high costs of bankruptcy for managers, see, for example, Stuart C. Gilson \& Michael R. Vetsuypens, CEO Compensation in Financially Distressed Firms: An Empirical Analysis, 48 J. FIN. 425, 426 (1993), and Lynn M. LoPucki \& William C. Whitford, Bargaining Over Equity's Share in the Bankruptcy Reorganization of Large, Publicly Held Companies, 139 U. PA. L. REV. 125, 149-51 (1990).

23. See John C. Coffee, Jr. \& William A. Klein, Bondholder Coercion: The Problem of Constrained Choice in Debt Tender Offers and Recapitalizations, 58 U. CHI. L. REV. 1207, 1241-42 (1991).

24. See id. at 1216. 
may be able to use an exit amendment to push through an exchange offer that few, if any, of the bondholders actually wanted. ${ }^{25}$

To be effective, the argument goes, exit amendments to the old bonds must impair the secondary market value of those bonds after the exchange, reduce the likelihood of the bonds eventually being repaid, or make it harder for a nonparticipating creditor to pursue legal remedies against the issuer. The prospect of being left with such a weakened bond might induce a holder to accept the exchange-even if that holder were not persuaded that the exchange made sense-simply because he does not wish to take the chance that twothirds of the other bondholders will agree to the offer and approve the disfiguring amendments. It is thus a version of the prisoner's dilemma, one most likely to exist in cases in which the bonds are widely dispersed and the holders have no effective way to communicate with each other. ${ }^{26}$

Not all academic commentators were hostile to the use of exit consents in corporate bond exchanges. The specter of dispersed, uncoordinated, and uncommunicative bondholders, they insisted, was unduly alarmist. In fact, the corporate bond market is dominated by large, sophisticated institutional buyers that are accustomed to communicating with each other on matters of mutual concern. ${ }^{27}$ Further, the empirical evidence failed to demonstrate any significant loss of value for the bondholders as a result of the requested covenant changes. ${ }^{28}$ This tended to support the inference that issuers were using the exit consents in the benign way (to keep holdouts from disrupting an offer that is in the best interest of the issuer and the bondholders) as opposed to a pernicious way (attempting to cheat unwary or disorganized bondholders). ${ }^{29}$

25. See Victor Brudney, Corporate Bondholders and Debtor Opportunism: In Bad Times and Good, 105 HARV. L. REV. 1821, 1833-34 (1992); Coffee \& Klein, supra note 23, at 1212, 122433; Zohar Goshen, Controlling Strategic Voting: Property Rule or Liability Rule?, 70 S. CAL. L. REV. 741, 785-88 (1997); Roe, supra note 17, at 248-49.

26. This objection could presumably be addressed by an exchange offer in which the issuer agreed, up front, to keep the offer open for some period of time after it had received (and publicly announced) subscriptions at a level sufficient to effect the exit amendments. As a tactical matter, of course, this approach runs the risk that bondholders will simply not respond to the initial exchange solicitation until they receive the notice from the issuer that the deal is going ahead. Cf. Coffee \& Klein, supra note 23, at 1244-45 (suggesting that one way of eliminating the prisoner's dilemma problem is for the debtor to conduct a "prior vote" in which the bondholders decide whether they want to receive an offer containing an exit consent).

27. See Royce de R. Barondes, An Economic Analysis of the Potential for Coercion in Consent Solicitations for Bonds, 63 FORDHAM L. REV. 749, 781-81 (1994); Marcel Kahan, The Qualified Case Against Mandatory Terms in Bonds, 89 Nw. U. L. REV. 565, 584-86, 618 (1995) Thereinafter Kahan, The Qualified Casel; Lewis S. Peterson, Note, Who's Being Greedy? A Theoretical and Empirical Examination of Holdouts and Coercion in Debt Tender and Exchange Offers, 103 YALE L.J. 505, 508 (1993); Kahan, supra note 12 , at 28 .

28. See Marcel Kahan \& Bruce Tuckman, Do Bondholders Lose From Junk Bond Covenant Changes?, 66 J. BuS. 499, 512 (1993); Peterson, supra note 27, at 509.

29. See Peterson, supra note 27, at 509. 


\section{Legal Validity of Exit Consents}

Notwithstanding the criticisms, most exit consent solicitations in corporate bond exchanges have thus far withstood legal challenge.

One starts with the proposition that when a bond contains a clause permitting certain types of amendments to be made with the consent of a specified percentage of bondholders, the issuer of that bond is free at any time to seek the consent of the required bondholders to such an amendment. After all, one important purpose of an amendment clause in a multicreditor debt instrument is to allow the creditor group-within whatever limitations are set out in the clause-to revise the terms of the instrument in light of changed circumstances. Relaxing the terms of the instrument may be preferable to forcing the debtor into open default. A purchaser of such a bond knows from the outset that the instrument contains an element of syndicate democracy and presumably (judging from the popularity of such clauses among bond drafters) most investors view this flexibility as desirable.

The queasiness that some observers experience in the face of exit amendments is therefore attributable entirely to the exit feature: The folks voting for these amendments are not the folks who will have to live with them. At the very least, it seems impolite to disfigure a debt instrument by amendment once one has made a commercial decision to leave that instrument. The legal question is whether a bondholder staying behind can claim that either the issuer of the bonds or the exiting bondholders have been guilty of something more than bad manners.

\section{The Position of the Bond Issuer}

The leading case on exit consents, Katz v. Oak Industries Inc. ${ }^{30}$ involved an application by a bondholder of Oak Industries, Inc. (Oak) for a preliminary injunction to restrain the company from completing an exchange offer for its outstanding debt securities. ${ }^{31}$ Oak was at the time in deep financial trouble. ${ }^{32}$ The company had entered into agreements with Allied-Signal, Inc. (Allied) for the cash sale to Allied of one of Oak's operating divisions and the purchase by Allied, again for cash, of ten million shares of Oak's common stock. Both of these agreements with Allied were conditioned upon

30. 508 A.2d 873 (Del. Ch. 1986). For a recent discussion of Katz and some of the other leading corporate bond cases, see Frederick W. Lambert, Path Dependent Inefficiency in the Corporate Contract: The Uncertain Case with Less Certain Implications, 23 DEL. J. CORP. L. 1077, 1148-53 (1998).

31. See Katz, 508 A.2d. at 875.

32. See id. 
Oak's reacquiring, by exchange, not less than 85 percent of its outstanding debt securities. ${ }^{33}$

Oak made an offer to exchange its outstanding convertible notes for a specified number of common shares of the company. Holders of each other series of Oak's long-term debt securities were invited to tender those instruments in return for a "Payment Certificate" that would entitle the debtholder to a cash payment-ranging from 65 percent to 91 percent of the face value of the tendered debts, depending on which series was tendered-five days after the sale of Oak's operating division to Allied-Signal. ${ }^{34}$ Significantly, these cash values represented a premium over the market prices for Oak's debt instruments at the time the offer was made. ${ }^{35}$

Debtholders who tendered their securities in this offer were required to consent to amendments of the governing indentures that would, among other things, strip away all financial covenants binding on Oak. These exit amendments, the court found, would remove "significant negotiated protections" to holders of Oak's outstanding debt securities and could have "adverse consequences to debt holders who elect not to tender" in the exchange offer. ${ }^{36}$

One of Oak's bondholders sought to enjoin the exchange offer on the grounds that it was "coercive" and violated Oak's obligation to act in good faith with respect to its bondholders. ${ }^{37}$ The Delaware Court of Chancery, in a 1986 opinion by Chancellor William Allen, refused to grant this injunction. Chancellor Allen reasoned:

(1) The relationship between a corporation and its debtholders is contractual in nature, and implicit fiduciary responsibilities on the part of the corporation should not be read into this relationship. ${ }^{38}$

(2) Even if the terms of Oak's exchange offer could be characterized as "coercive," this characterization alone was of "limited analytical utility"; the important issue was whether the coercion was wrongful. ${ }^{39}$

(3) The appropriate legal test for determining whether Oak breached an obligation to deal fairly and in good faith with its bondholders was whether the parties who negotiated the terms of those instruments, had they foreseen the exchange offer

33. See id. at 876 .

34. See id. at 876-77.

35. See id. at 881.

36. Id. at 877 .

37. See id. at 878 .

38. See id. at 879.

39. Id. at $879-80$. 
and consent solicitation Oak eventually made, would have forbidden such an action. ${ }^{40}$

(4) In this case, the parties to the underlying indentures, had they foreseen Oak's offer, may well not have prevented Oak from making an offer to all bondholders that returned in cash to participating holders more than the then-current market price of the securities.

(5) Oak's Board of Directors, in approving these arrangements, may have reasonably concluded that this represented "the last good chance to regain vitality for the enterprise."

Several months later, Chancellor Allen again had occasion to consider the subject of structural coercion in corporate bond offers, although this time the issuer was looking only to amend its existing bonds, rather than exchange them. In Kass v. Eastern Airlines, ${ }^{42}$ Eastern Airlines (Eastern) requested amendments to its outstanding bonds in order to permit it to pay a cash dividend to its shareholders following a proposed merger. ${ }^{43}$ Such dividends were precluded by the relevant bond indentures because Eastern was at that time out of compliance with the financial ratios specified in those indentures.

To induce bondholders to accept these amendments, Eastern offered each consenting bondholder either a cash payment of $\$ 35$, or $\$ 125$ worth of Eastern ticket vouchers. ${ }^{44}$ The plaintiff in Kass characterized this as "vote buying" that violated public policy and constituted a breach of Eastern's implied duty to deal fairly and in good faith with its bondholders. ${ }^{45}$

Chancellor Allen rejected both of these arguments. There is nothing wrong with vote buying on the part of a bond issuer, he concluded, as long as the offer is made on equal terms to all bondholders. ${ }^{46}$ As for the good faith and fair dealing objection, Chancellor Allen referred the plaintiffs to his opinion in the Katz case handed down only a few months previously. ${ }^{47}$ Kass

\footnotetext{
40. See id. at 880 .

41. Id. at 882 .

42. 1986 Del. Ch. LEXIS 486 (Del. Ch. Nov. 14, 1986).

43. See id. at *2-*3.

44. See id. at $* 4$.

45. See id. at $* 4, * 8$.

46. See id. at *12; cf. In re Figter Ltd., 118 F.3d 635, 640 (9th Cir. 1997) (finding that the defendant creditor who purchased majority of a class of claims, and thereby rendered the debtor's plan unconfirmable, had acted in good faith, in part because the defendant had offered to purchase all of the claims in that class).

47. See Kass, 1986 Del. Ch. LEXIS 486, at *12-*13.
} 
was an unpublished disposition, but subsequent Delaware decisions have repeatedly cited Chancellor Allen's opinion in Katz with approval. ${ }^{48}$

Although New York courts have also noted Chancellor Allen's discussion of bondholder rights in Katz with approval, ${ }^{49}$ they have rarely had occasion explicitly to consider the legal validity of exit consents. There are good grounds, however, for believing that New York courts would follow the lead of the Delaware case law in this area.

One recent New York federal district court decision (unpublished), however, may suggest that this technique can be pushed too far. In Federated Strategic Income Fund v. Mechala Group Jamaica Ltd., ${ }^{50}$ the debtor corporation sought the consent of bondholders to moving the corporation's assets to another entity (not an obligor of the bonds) and to eliminating certain guarantees for the bonds. After the debt exchange, therefore, any remaining bondholders were faced with the prospect of suing a borrower without assets. $^{51}$ Judge Harold Baer, Jr. of the Southern District of New York held that this solicitation effectively impaired the remaining bondholders' rights to institute legal action to recover their claims. ${ }^{52}$ Interestingly, the bond indenture involved in this case had both a conventional prohibition on involuntary amendments to payment terms and a restriction (whose origin may also be found in section 316(b) of the Trust Indenture Act) on amendments that impair a bondholder's right to commence legal action to enforce his claim. ${ }^{53}$ Judge Baer found that the exit amendments being solicited by the debtor constituted an impairment of enforcement rights; he did not suggest that they were backdoor changes to the payment terms. ${ }^{54}$

The federal courts sitting in New York have adopted an approach to interpreting standard form contracts that is sometimes described as the boilerplate theory. ${ }^{55}$ Market participants, this theory contends, have a strong interest in seeing a uniform, predictable interpretation of standard provisions

48. See, e.g., Cincinnati SMSA Ltd. v. Cincinnati Bell Cellular Sys. Co., 708 A.2d 989, 992 (Del. 1998); Chamison v. Healthtrust, Inc.-Hosp. Co., 735 A.2d 912, 921 (Del. Ch. 1999), aff d, 748 A.2d 407 (Del. 2000).

49. See, e.g., United States v. Jolly, 102 F.3d 46, 48 (2d Cir. 1996) (citing Katz), vacated, 142 F.3d 552 (2d Cir. 1998).

50. 1999 WL 993648 (S.D.N.Y. Nov. 2, 1999).

51. See id. at *6.

52. See id. at *7.

53. See id. at *5-*6.

54. See id. at*7.

55. See Sharon Steel Corp. v. Chase Manhattan Bank, N.A., 691 F.2d 1039, 1048-52 (2d Cir. 1982); cf. Unigard Sec. Ins. Co., Inc. v. N. River Ins. Co., 4 F.3d 1049, 1071 (2d Cir. 1993) (applying the boilerplate theory); Marcel Kahan \& Michael Klausner, Standardization and Innovation in Corporate Contracting (or "The Economics of Boilerplate"), 83 VA. L. REV. 713 (1997) (analyzing standardized provisions in corporate contracts). 
in commercial contracts (so-called boilerplate provisions). ${ }^{56}$ When interpreting such provisions, at least according to one New York federal district court, great weight will be given by New York courts to relevant decisions in other jurisdictions, particularly when market participants can be presumed to have been aware of those other decisions but did not change their documentation practices in a way that might suggest disagreement with a prior judicial interpretation of a boilerplate clause. ${ }^{57}$

Katz was decided by a Delaware court in 1986 . Since then, not only have exit consents been the subject of considerable attention in legal journals, but the technique has been repeatedly used in corporate bond exchanges. ${ }^{58}$ If the drafters of bonds and bond indentures have not altered their approach to amendment clauses to preclude the use of exit consents of the kind discussed in Katz, the boilerplate doctrine should give New York judges a basis for following Delaware's approach to these issues.

\section{The Sovereign Context}

Katz involved a corporate debtor. The obvious question is whether the presence of a sovereign debtor would change the outcome. The key to Chancellor Allen's analysis in Katz lies in his finding that there are no implicit fiduciary duties running from the corporate debtor to its bondholders. The underlying rationale is that bond contracts are carefully negotiated by sophisticated parties, and there is no need for a court to infer such duties. Sovereign bond contracts are no different in terms of these institutional characteristics. The parties involved in the negotiation of a sovereign bond issued in

56. See Sharon Steel, 691 F.2d at 1048.

57. See Morgan Stanley \& Co. v. Archer Daniels Midland Co., 570 F. Supp. 1529, 1541-42 (S.D.N.Y. 1983). The Morgan Stanley case involved the adoption of an Illinois district court's interpretation of a standard provision. Regarding applications of New York law by the courts of other states, we are aware of an unpublished decision by the Ohio Court of Appeals in 1995. The Ohio court was applying New York law to evaluate a challenge to a debtor's offer of cash payments in exchange for consents by bondholders to amending the terms of an indenture. See Drage v. Santa Fe Pac. Corp., 1995 WL 396370, at *1-*2 (Ohio Ct. App. July 3, 1995). The court, in upholding the validity of the offer, followed Katz and Kass in deciding that there was nothing improper with the offer because "the indenture did not prohibit the payments offered by [the debtor] and [the debtor] made its offer to all senior debentureholders on the same terms." Id. at *6-7.

58. See Kahan, The Qualified Case, supra note 27, at 618-19. Additional factors pointing toward the market's likely familiarity with Katz are (1) that Katz was a published decision by Chancellor William Allen (now a Professor at New York University Law School) who was one of the most respected judges in the area of corporate law and (2) that Katz is standard fare in a number of the prominent corporate law casebooks that discuss bonds. See, e.g., WILLIAM BRATTON \& VICTOR BRUDNEY, CORPORATE FINANCE 238 (4th ed. 1993) (containing an edited version of Katz); WilLIAM A. KLEIN ET AL., BUSINESS ASSOCIATIONS 813 (3d ed. 1997) (same); LAWRENCE E. MitChell et Al., Corporate FinANCE AND GovernanCE 314 (2d ed. 1996) (same). 
the international market are just as sophisticated, and in relevant part, the contracts look remarkably similar to those in the corporate context.

In addition, the possible concern that a debtor will attempt to take advantage of a prisoner's dilemma type situation is no more visible in the sovereign bond context than it is in the corporate context. As discussed above, what gives rise to the prisoner's dilemma concern is the inability of bondholders to communicate effectively among themselves and coordinate their refusal of an offer that the majority of them do not like. Marcel Kahan and others have explained that because most corporate bonds tend to be held by large institutional players, improper coercion by corporate debtors is unlikely to be feasible. ${ }^{59}$ The institutional characteristics of the sovereign bond market are similar.

\section{The Position of the Exiting Bondholders}

Would majority bondholders subject themselves to some liability for agreeing to amend a sovereign bond (within the limitations set out in the relevant amendment clause) just before they exchange those instruments with the issuer?

a. Tortious Interference. It is fair to ask whether the exiting bondholders have tortiously interfered with the contract rights of those creditors electing to stay behind. The elements that must be shown to state a claim under New York law for tortious interference with contract are:

(1) the existence of a valid contract between the plaintiff and a third party;

(2) the defendant's knowledge of that contract;

(3) the defendant's intentional procuring of the breach of the contract; and

(4) damages. ${ }^{60}$

A holdout bondholder alleging tortious interference would therefore have to overcome two obstacles. First, such a claim would require a showing that the exiting bondholders had breached the contract (in this case, the old bond) - a difficult argument in the face of a clause in that bond expressly permitting amendments to nonpayment terms. Second, a court, at least a New York court, is likely to hold that only a stranger to a contract can be liable for tortious interference. ${ }^{61}$ If the alleged tortfeasor is a party to the

59. See sources cited supra note 27.

60. See CIBC Bank \& Trust Co. (Cayman) Ltd. v. Banco Cent. do Brasil, 886 F. Supp. 1105,1119 (S.D.N.Y. 1995).

61. See id. at 1119-20. 
contract (as would be the case with exiting bondholders), the plaintiffs remedy is limited to an action for breach of contract.

b. Implied Duties. Have the exiting bondholders violated an implied duty of good faith and fair dealing toward their erstwhile fellow creditors? The answer to this question calls for an investigation into a surprisingly underdeveloped area of financial law: Whether creditors owe to each other some implicit duties when they elect to advance money to a borrower pursuant to a multicreditor debt instrument such as a syndicated loan, a syndicated participation agreement, or a bond issue.

Some early decisions were prepared to infer such duties when debtholders acted collusively with the borrower to harm other creditors. In Hackettstown National Bank v. D.G. Yuengling Brewing Co., ${ }^{62}$ for example, the owner of a debtor corporation entered into an agreement with a third party designed to facilitate the purchase of a sufficient number of the corporation's bonds in order to allow the principal stockholder to control three-fourths of the voting power under the bonds. The stockholder then coordinated an amendment of the bonds to defer payments for five years (something that the amendment clause in the bonds permitted with the consent of 75 percent of the holders) "with a view of enabling him ... to compel the minority bondholders to sell their bonds on such terms as he might dictate." ${ }^{163}$

The Second Circuit Court of Appeals held this to be a "corrupt and unwarranted exercise of the power of the majority" of bondholders. ${ }^{64}$ The court did not question the right of bond purchasers to vote for "an honest consent to postpone payments due," but concluded that this did not authorize a purchaser to acquire bonds "in a conspiracy to defraud minority bondholders." ${ }^{65}$

Subsequent to the Hackettstown decision, Congress passed the Trust Indenture Act of 1939 that requires, for trust indentures that must be qualified under the Act, a disenfranchisement of voting of bonds "owned by any obligor... or by any person directly or indirectly controlling or controlled by or under direct or indirect common control with any such obligor."

Apart from openly collusive arrangements with the debtor designed to impair the rights of minority creditors, however, U.S. courts have been very reluctant to find implicit intercreditor duties in instruments of this kind. The issue has come up in a variety of contexts. Lending banks in a syndicated credit facility did not breach duties to a fellow lender when they refused to accelerate the loan following the borrower's default, even though

\footnotetext{
62. 74 F. 110 (2d Cir. 1896).

63. Id. at 114 .

64. Id.

65. Id.

66. 15 U.S.C. $\$ 77 \mathrm{ppp}(\mathrm{a})$ (1994).
} 
this kept the dissenting bank from pursuing remedies against the borrower. ${ }^{67}$ In a syndicated loan participation arrangement, the lead bank did not breach its contractual responsibilities to a participant when it agreed with other participants to waive the borrower's default and not to accelerate the debt. ${ }^{68}$ A federal district court in New York refused to apply the Hackettstown doctrine to a situation in which an affiliate of a sovereign debtor deliberately positioned itself to command the voting power required to stop an acceleration of a syndicated debt instrument despite a long-standing payment default. ${ }^{69}$ An aberrant decision of a New York state court judge in 1985, holding that banks in a syndicated loan owed each other implicit fiduciary duties (in that case, the duty not to commence a legal action against the borrower unless the majority of the syndicate approved of this behavior), ${ }^{70}$ has been heavily criticized and distinguished. ${ }^{71}$

The lesson of these cases is that creditors should not rely on a vague sense of implicit intercreditor duties when they enter into multiple lender transactions. If the black letter of the debt instrument in question gives each lender the right to vote for certain types of amendments or waivers, only very extraordinary circumstances will justify disregarding such a vote. Selfishness on the part of the lenders casting such a vote, their manifest disdain for the Golden Rule, their lack of empathy or charity toward other creditors, or even profound ignorance as to what might be in their (or anyone else's) best interests, are not adequate grounds for disenfranchisement. Moreover, the proponent of the theory that lenders owe each other an implicit duty not to take actions that might injure or frustrate another lender might find that this argument proves too much. After all, if such implicit duties do exist, may

67. See First Nat'l Bank Ass'n v. Canadian Imperial Bank of Commerce, 1995 U.S. Dist. LEXIS 12105, at *24-25 (D. Minn. June 9, 1995); New Bank v. Toronto-Dominion Bank, 768 F. Supp. 1017, 1021 (S.D.N.Y. 1991) ("Courts have generally refused to rewrite agreements to provide minority lenders with any rights, such as the 'implied' right sought here by [the plaintiff], which are not expressly set forth in the agreements.").

68. See First Nat'l Bank v. Cont'l Ill. Nat'l Bank \& Trust Co., 933 F.2d 466 (9th Cir. 1991); see also First Citizens Fed. Savs. \& Loan Ass'n v. Worthen Bank \& Trust Co., 919 F.2d 510, 514 (9th Cir. 1990) ("In the context of loan participation agreements among sophisticated lending institutions, we are of the opinion that fiduciary relationships should not be inferred absent unequivocal contractual language ....").

69. See CIBC Bank \& Trust Co. (Cayman) Ltd. v. Banco Cent. do Brasil, 886 F. Supp. 1105, 1115 n.8 (S.D.N.Y. 1995).

70. See Credit Francais Int'l, S.A. v. Sociedad Financiera de Comercio, C.A., 490 N.Y.S.2d 670, 684 (N.Y. Sup. Ct. 1985).

71. See Lee C. Buchheit, Is Syndicated Lending a Joint Venture?, INT'L FIN. L. REV., Aug. 1985, at 12; Lee C. Buchheit \& Ralph Reisner, The Effect of the Sovereign Debt Restructuring Process on Inter-Creditor Relationships, 1988 U. ILL. L. REV. 493, 502-04. 
not the majority lenders rely on them to force dissidents into accepting the judgment of the majority concerning an action such as a proposed amendment? $?^{72}$

c. Reputation. Even if voting for an exit amendment does not expose the exiting creditor to legal liability, some institutions may worry that their business reputation will be tarnished by participating in an arrangement that could be characterized as a gratuitous swipe at fellow lenders. This may be a legitimate concern in some cases and will depend on the nature of the exit amendments, the commercial interests that the exiting creditors are seeking to protect through the amendments, and the extent to which the changes enacted by those amendments are seen as proportional to the threat posed by the holdout creditors. Collusive arrangements with the sovereign borrower, or amendments that cannot be justified by reference to the legitimate commercial interests of those accepting the exchange offer, obviously pose the greatest risk to reputation. The practice of using exit consents in corporate bond exchanges, however, does not seem to have resulted in reputational damage to participating creditors, nor has there even been any widespread change to the drafting of amendment clauses in corporate bonds following the unveiling of the exit consent technique in the 1980s. ${ }^{33}$

\section{Exit Amendments in Sovereign Bonds}

The loan agreements and restructuring agreements that evidenced sovereign debt owed to commercial banks in the 1980s and early 1990s generally called for the unanimous approval by the lending banks before any amendment could reduce amounts payable under the agreement or defer the due dates of payments. ${ }^{74}$ By the end of the 1980 s, a limited flexibility began to appear in the amendment clauses in some of these agreements permitting, for example, changes to payment terms with the consent of lenders

72. Some U.S. courts (most notably those in Massachusetts) have held that minority shareholders in close corporations are constrained in their exercise of negotiated veto rights by duties of "utmost good faith and loyalty" owed to other shareholders. See Smith v. Atl. Props., Inc., 422 N.E.2d 798, 801 (Mass. App. Ct. 1981) (quoting Donahue v. Rodd Electrotype Co., 328 N.E.2d 505, 593 (Mass. 1975)); see also A.W. Chesterton v. Chesterton, 128 F.3d 1, 6 (1st Cir. 1997) (citing Smith with approval). The Delaware Supreme Court, however, has indicated its reluctance to embrace (or at least infer) similar intrashareholder duties. See Nixon v. Blackwell, 626 A.2d 1366, 1379-81 (Del. 1993). More important, we are not aware of any U.S. court decision suggesting that creditors owe each other similar duties. Cf. In re W.T. Grant Co., 699 F.2d 599, 609-10 (2d Cir. 1983) (" $[\mathrm{A}]$ creditor is under no fiduciary obligation to its debtor or to other creditors of the debtor in the collection of its claim" (quoting In re W.T. Grant Co., 4 B.R. 53, 75 (Bankr. S.D.N.Y. 1980))).

73. See Kahan, The Qualified Case, supra note 27, at 618-19.

74. See Lee C. Buchheit, Making Amends for Amendments, INT'L FIN. L. REV., Feb. 1991, at 11. 
holding only 95 percent of the loan. ${ }^{75}$ When the commercial bank debt restructuring process finally ended in the early 1990s, through an exchange of restructured syndicated bank loans for new bonds (called "Brady bonds" after the incumbent U.S. Treasury Secretary Nicholas Brady), exit amendments affecting the old loan agreements were not widely used as a technique for encouraging full creditor participation in the exchange. ${ }^{76}$ This may be explained in part by the fact that most sovereign debt restructurings over this period, including all of the Brady bond exchanges, were negotiated with informal advisory or steering committees composed of representative commercial bank creditors. ${ }^{77}$ These committees were fragile creatures of convenience: They did not receive a mandate from other creditors to conduct negotiations on behalf of those other creditors, and the committees were thus understandably reluctant to endorse any arrangements that could be seen as coercive by some other lenders. ${ }^{78}$

For this purpose, the provisions of a sovereign bond governed by the law of a U.S. jurisdiction (together with its related indenture or fiscal agency agreement) fall into one of the following three categories: (1) those provisions that are specifically identified in the amendment clause as requiring the consent of each affected bondholder before an amendment, modification, or

75. See id. at 12 .

76. There were one or two gentle stabs at using exit amendments in this process. By signing the Brady exchange agreements for Brazil, for example, the creditors agreed to amend the restructuring agreements they were exiting by, among other things, removing the negative pledge protection and certain events of default. See Republica Federativa do Brasil, 1992 Financing Plan, at pt. IV (Dec. 29, 1992) (unpublished plan, on file with authors). Poland's Brady bond exchange required lenders to consent to an amendment of the negative pledge and sharing clauses in the old restructuring agreements that might otherwise have interfered with the Brady exchange. See The Republic of Pol., 1994 Financing Proposals 26 (May 23, 1994) (unpublished proposals, on file with authors) [hereinafter The Republic of Pol., 1994 Financing Proposals]. The Brady exchange programs for several other countries called for similar amendments to the old restructuring agreements.

77. See Lee C. Buchheit, Advisory Committees: What's In a Name?, INT'L FIN. L. REV., Jan. 1991 , at $9,10$.

78. But this bashfulness had its limits. The Brady bond exchanges done under English law (but, interestingly, not under New York law) often contained a covenant on the part of the sovereign borrower not to enter into a voluntary arrangement or compromise with a holdout creditor on terms more favorable to the holdout than those being offered to the participating creditors without making the same offer to those lenders that had accepted the exchange. See The Republic of Pol., 1994 Financing Proposals, supra note 76, at 37-38. This would, of course, be a financial impossibility for most sovereigns and a legal nightmare to implement. This in terrorem device was intended to put pressure on prospective holdout creditors by making it impossible, in a practical sense, for the sovereign to settle with holdouts on more favorable terms than those being given to the participating lenders. The fig leaf for the steering committees that negotiated these deals, however, was that the sovereign was theoretically free to settle with holdouts as long as it was prepared to make the same offer to everyone else. See, e.g., id. at 37-38 (clause 6.8). 
waiver will be effective (Unanimous Consent Matters) $;^{79}$ (2) any provision that, although not specifically identified as a Unanimous Consent Matter, could nonetheless have the practical effect of subverting a Unanimous Consent Matter if amended or removed from the bond; and (3) all other provisions of the bonds and accompanying indentures or fiscal agency agreements (apart from those that deal with the trustee or fiscal agent, which typically cannot be amended without the consent of those institutions).

Category 1 is clear: No amendment to a Unanimous Consent Matter will bind bondholders who do not accept the amendment. Category 2 is not at all clear: The governing law clause of a bond, for example, is not usually a Unanimous Consent Matter. But if, through an exit amendment, the governing law of the old bond were changed to the law of the sovereign's own jurisdiction, and if that law purported to abrogate the sovereign's obligation to repay the bond, could such an amendment be challenged as a disguised change to a Unanimous Consent Matter requiring the approval of all bondholders?

To take another Category 2 example, bonds normally provide for a right of acceleration following the occurrence of an event of default and a vote of a specified percentage of outstanding bonds. Could an exit amendment remove all Events of Default and this acceleration remedy in the old bond, thereby leaving nonparticipating bondholders to sue for missed payments only as and when those payments fall due according to their original terms? Or would removing the acceleration remedy be seen as indirectly affecting the timing of payments due on the bond (in this case, the timing of payments following a default and acceleration), and thus be entitled to treatment as a Unanimous Consent Matter?

Chancellor Allen's test in Katz (would the drafters of the bonds, had they foreseen the possibility of the exit amendment, have allowed it to be made with less than unanimous approval) gives wide room for judicial discretion. ${ }^{80}$ Of course, nearly fifteen years have elapsed since Katz was decided, and it may be increasingly untenable to argue that bond drafters would have expanded their list of Unanimous Consent Matters to include

79. Typically, Unanimous Consent Matters include the amount or date of any payment due under the bonds, the currency of such payments, the place of payments and the percentages required for votes to amend the instrument.

80. The original test set out by Chancellor Allen for implying a term (it has to be "clear" from the express terms of the contract that, had the parties foreseen this contingency, they would have agreed to bar the conduct in question, see Katz v. Oak Indus. Inc., 508 A.2d 873, 880 (Del. Ch. 1986)) was extremely narrow. Ten years later, however, Chancellor Allen himself suggested that the bar may have been set too high in Katz and that the more appropriate test might be "it is more likely than not." See Schwartzberg v. CRITEF Assocs. Led. P'ship, 685 A.2d 365, 376 (Del. Ch. 1996); see also Cincinnati SMSA L.P. v. Cincinnati Bell Cellular Sys. Co., 708 A.2d 989, 992-93 (Del. 1998) (citing Schwartzberg on the topic); In re Marriott Hotel Prop. Il, Ltd., No. CIV.A.14961, 2000 WL 128875, at *15_*16 (Del. Ch. Jan. 24, 2000) (same). 
Category 2 amendments had they only thought about the question. The accumulated weight of the hundreds of conventional sovereign bond indentures and fiscal agency agreements governed by the law of a U.S. jurisdiction executed since the Katz decision in 1986 lends considerable support to the argument that only the provisions of these documents specifically enumerated as Unanimous Consent Matters were intended by the drafters to require the unanimous consent of the bondholders.

Category 3 provisions, however, may be amended with the consent of only the specified majority or supermajority of bondholders. The amendment or removal of some of these provisions could adversely affect the secondary market value of the old bond after the exchange or make it more difficult for remaining holders of the old bond to pursue legal remedies against the sovereign issuer. By way of example, but only by way of example, the following clauses could be candidates for an exit amendment:

Waiver of immunity. Some, but certainly not all, sovereign bonds contain an express waiver of jurisdictional immunity for lawsuits against the sovereign and any immunity that the sovereign's property might enjoy from attachment or execution. Even a limited exit amendment that removed the express waiver of immunity for foreign state property may mean that a remaining holdout creditor could not obtain prejudgment attachment of the sovereign borrower's assets in the United States in connection with a lawsuit based on the old bonds, ${ }^{81}$ nor could it seize such property to satisfy a judgment, unless (1) the sovereign was held to have implicitly waived this immunity or (2) the seized property "is or was used for the commercial activity upon which the claim is based" ${ }^{\prime \prime 2}$ (an unlikely circumstance in the context of a bond issue in which the cash proceeds will long since have been spent).

Submission to Jurisdiction. The sovereign issuer's express submission to the jurisdiction of foreign courts (including the appointment of agents to receive service of process in those jurisdictions) could be revised.

81. See 28 U.S.C. $\$ 1610(\mathrm{~d})(1)$ (1994). This section of the Foreign Sovereign Immunities Act gives foreign state property immunity from prejudgment attachment unless there has been an explicit waiver by the foreign state. Such a waiver, however, will be given effect "notwithstanding any withdrawal of the waiver the foreign state may purport to effect except in accordance with the terms of the waiver." Id. This qualification appears to be directed at unilateral withdrawals of a waiver by a foreign state, not at removals of a waiver by an amendment to the underlying contract approved in accordance with the provisions of that agreement. The legislative history of the waiver withdrawal language confirms this reading. See H.R. REP. NO. 94-1487, at 18, 28 (1976), reprinted in 1976 U.S.C.C.A.N. 6604, 6629; S. REP. NO. 94-1310, at 18, 27 (1976).

82. Id. $\$ 1610(\mathrm{a})(1)$ (containing the same qualification about the effect of a withdrawal of the waiver by the foreign state referred to supra note 81 ). 
Financial covenants. Financial covenants binding the issuer, such as negative pledge restrictions, could be watered down or removed from the old bonds.

Listing. The obligation on the part of the issuer to keep the bonds listed on a stock exchange could be removed, thereby reducing the liquidity of the bonds.

Any such exit amendment made to the old bond in connection with an exchange would, for all practical purposes, be permanent. The consent of the issuer, as well as a specified majority of holders, is typically required for amendments. Accordingly, the holdouts could not, following the exchange, reverse the changes made by the exiting bondholders because the issuer would not agree to such a reversal.

\section{E. The Justification for Using Exit Amendments in Sovereign Bond Exchanges}

The unabashed objective of an exit amendment is to encourage all other bondholders to accept the exchange once the majority or supermajority of bondholders has decided to do so. Inherent in any multicreditor debt instrument, such as a bond or syndicated loan that permits amendments to nonpayment terms with the consent of less than all of the creditors, is the possibility that the required majority will in fact use that power to make such amendments.

As noted above, ${ }^{83}$ sovereign bonds governed by English law typically permit any provision of the instrument, even payment terms, to be amended by an action of a supermajority of the bondholders. The presence of Unanimous Consent Matters in U.S.-style sovereign bonds is a result of the drafting conventions that followed the adoption of the Trust Indenture Act in 1939. Moreover, in the bankruptcy of a corporate issuer, the law openly sanctions forcing a compromise on dissident creditors when certain conditions are met. There is thus nothing illegal, unusual, unsavory, or ungentlemanly in a majority

83. See supra note 15. The exchange offer launched by the Ukraine in February 2000 (covering five series of the Ukraine's Eurobonds, four of which contained English-style majority action clauses) used the majority action clauses to encourage full participation by all creditors. By accepting the Ukraine's exchange offer, each exiting creditor automatically gave its proxy to the Principal Exchange Agent to vote for the amendment of the old bonds to conform their payment terms to those of the new Ukrainian bonds being issued in the exchange. See THE CABINET OF MINISTERS OF UKR., supra note 13, at 105-37. Prospective holdouts were in effect being told that holding out offered no benefit: They would not be entitled to payment under their old bonds on any better terms than creditors taking the new bonds. This bit of coercion does not appear to have attracted any disapproval from the market. See Arkady Ostrovsky \& Thomas Catan, Restructuring Wins Approval of Bondholders, FIN. TIMES, Mar. 15, 2000, at 12.

84. See supra text accompanying note 18. 
using its contractual amendment power in a multicreditor debt instrument to protect its own interests.

Using exit consents in a sovereign bond exchange to minimize the holdout creditor problem has the following advantages when compared with proposals to enact, at the national or supranational level, bankruptcy-style protections for sovereign borrowers:

(1) It requires no change to existing laws or standard bond documentation.

(2) By definition, these actions are taken only at the time the sovereign has worked out a restructuring program acceptable to the broad majority of its bondholders. Thus, no sovereign can be sure of its ability to secure the necessary majority or supermajority approval in advance.

(3) Through exit consents, the majority of creditors help to ensure that neither they nor the sovereign are exploited by a dissident minority of creditors. Importantly, this involves the financial community as a whole protecting itself against opportunistic behavior by its maverick elements, rather than the official sector intervening to suspend private creditor remedies as a means of promoting orderly sovereign debt workouts.

(4) The desire to obtain the exit consent should induce a sovereign issuer to make an exchange offer that it believes will attract the necessary supermajority support from bondholders. This indirectly strengthens the negotiating hand of the bondholders in the workout discussions.

\section{CONCLUSION}

Using exit amendments in sovereign bond exchanges to address the holdout creditor problem may thus be less damaging to the fabric of the international financial system than the other alternatives now being discussed. Suppressing holdout creditor behavior is not the overriding objective. The overriding objective is to find a procedure that will, when necessary, permit an orderly rearrangement of sovereign bond indebtedness without discouraging private capital flows to emerging market countries.

While this Article was in the editing process, the Republic of Ecuador launched an offer to exchange its existing Brady bonds and Eurobonds for new debt instruments to be issued by Ecuador. ${ }^{85}$ The transaction was designed

85. Lee Buchheit's law firm represented the Republic of Ecuador in this transaction. See REPUBLIC OF ECUADOR, OFFER TO EXCHANGE (July 27, 2000). 
to reduce the size of this stock of debt by about 40 percent and to provide Ecuador with considerable cash flow relief over the early years. ${ }^{86}$

For the first time in a sovereign bond exchange involving bonds governed by New York law, Ecuador included a number of exit amendments to the old bonds as a means of encouraging full participation in the offer. By accepting the offer, for example, tendering bondholders automatically agreed to amend the old bonds to remove the crossdefault and negative pledge clauses, to allow Ecuador to reacquire and to hold certain of its Brady bonds (thereby making it impossible for remaining bondholders to accelerate those instruments after the exchange), and to delist the old bonds. ${ }^{87}$

The transaction was successful. Approximately 97 percent of bondholders accepted the offer. ${ }^{88}$ Comments by bondholders to journalists suggest that the presence of these exit amendments in the exchange played a significant role in persuading some bondholders to participate. ${ }^{89}$

86. See Ecuador Announces Bond Swap to Slash Foreign Debt, AGENCE FR.-PRESSE, Sept. 15, 2000, available at 2000 WL 246901509.

87: See REPUBLIC OF ECUADOR, supra note 85 , at 9-12.

88. See Press Release, Ecuador Closes Debt Exchange (Aug. 23, 2000).

89. See, e.g., Jane Bussey, Ecuadorean Bondholders Reluctantly Accept Bond Swap After Government Default, KNIGHT-RIDDER TRIB. BUS. NEWS, Aug. 15, 2000, available at 2000 WL 25443307; David I. Oyama, World Watch: Ecuador Expects Creditor Approval of Restructuring, WALL ST. J., Aug. 14, 2000, at A12. 